\title{
A Rare Cause of Acute Abdomen: Ruptured Splenic Artery Aneurysm
}

\author{
Akut Karının Nadir Bir Sebebi: Splenik Arter Anevrizma Rüptürü \\ ๑ Cihan Bedel, ๑ Abdülkerim Şalkacı* \\ University of Health Sciences, Antalya Training and Research Hospital, Clinic of Emergency Medicine, Antalya, Turkey \\ * Süleyman Demirel University Faculty of Medicine, Department of Radiology, Isparta, Turkey
}

Abstract

Ruptured splenic artery aneurysm (SAA), rare in the emergency department (ED), is a cause of hypotension and abdominal pain. Physicians should consider the possibility of this condition especially in patients with abdominal pain and hypotension. In this paper, we report the case of a patient with ruptured SAA presenting to the ED as an intraabdominal catastrophe and review the key features of this entity.

Keywords: Splenic artery, aneurysm, rupture
Öz

Splenik arter anevrizma (SAA) rüptürü, acil serviste (AS) görülen hipotansiyon ve karın ağrısının nadir bir nedenidir. Acil hekimleri, karın ağrısı ve hipotansiyonu olan hastalar için bu tanı olasılığını düşünmelidir. Biz bu olguda AS'ye başvurmuş karın içi katastrof olan SAA rüptürü olan bir olguyu ve bunun temel özelliklerini gözden geçirdik.

Anahtar Sözcükler: Splenik arter, anevrizma, rüptür

\section{Introduction}

Acute abdominal pain is one of the most common complaints in patients presenting to emergency departments (EDs). The differential diagnosis list of abdominal pain is so long that some pathologies can be ignored because of their rarity. Splenic artery aneurysm (SAA) is the most common aneurysm after aortic and iliac artery aneurysm in patients with intrabdominal aneurysms, although it is a very rare clinical diagnosis in ED. The prevalence of SAA has been reported to be $0.8 \%$; in large autopsy series, this rate was $0.04 \%-0.1 \%$ (1). Congenital and acquired conditions play a role in the development of SAA. Also, some of the risk factors are trauma, septic embolism, cardiovascular diseases, atherosclerosis, and hypertension. The patient may be asymptomatic, however, SAA rupture may cause destructive bleeding with high mortality $(2,3)$. We, here report a patient who was admitted to the ED with abdominal pain and diagnosed as having ruptured SAA.

\section{Case}

A 60-year-old female patient presented to the ED with the complaints of left upper quadrant and flank pain and nausea for about three hours. Physical examination revealed rebound tenderness in the upper quadrant (epigastric and left upper). There was no pulsatile abdominal mass and rectal examination showed no stool in the rectal vault. Her past medical history included essential hypertension. She had no history of abdominal trauma, pancreatitis or chololitiasis. The patient was pale and sweaty. The patient was mildly hypotensive (100/70 $\mathrm{mmHg}$ ) and tachycardic (120 beats/min). The other vital parameters were within the normal limits. The patient had hypoactive bowel sounds and costovertebral angle tenderness. The laboratory test results on admission were within the normal limits except slightly elevated white cell count $(12.500 / \mathrm{mL})$, C-reactive protein raised to 48 $\mathrm{mg} / \mathrm{L}$ (normal: $0-3 \mathrm{mg} / \mathrm{L}$ ), and slightly low hemoglobin level $(8.1 / \mathrm{dL})$. Electrocardiogram on admission showed sinus tachycardia. Urine dipstick test and chest $\mathrm{X}$-ray
Address for Correspondence/Yazışma Adresi: Cihan Bedel

University of Health Sciences, Antalya Training and Research Hospital, Clinic of Emergency Medicine, Antalya, Turkey

Phone: +90 5075641254 E-mail: cihanbedel@hotmail.com ORCID ID: orcid.org/0000-0002-3823-2929

Received/Geliş Tarihi: 10 January 2018 Accepted/Kabul Tarihi: 12 April 2018
${ }^{\circ}$ Copyright 2019 by The Medical Bulletin of istanbul Haseki Training and Research Hospital The Medical Bulletin of Haseki published by Galenos Yayınevi.

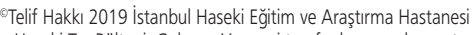
Haseki Tıp Bülteni, Galenos Yayınevi tarafından yayınlanmıştır. 
were normal without any sign requiring urgent surgery. A bedside ultrasonography was performed and free abdominal fluid was observed. The patient was referred to the radiology department. Computed tomography showed hemoperitoneum due to ruptured SAA (Figures 1, 2). The patient was immediately admitted to the operating room for laparoscopic surgery. The postoperative course was uneventful and the patient was discharged five days after surgery without any complication. Patient's consent to publication was obtained.

\section{Discussion}

SAA is the most common aneurysm after aortic and iliac artery aneurysm in patients with intrabdominal aneurysms, although it is a very rare clinical diagnosis in ED. The prevalence of SAA is less than one percent and it was reported that this rate was below $0.1 \%$ in large autopsy series. Although SAA is more common in females than in

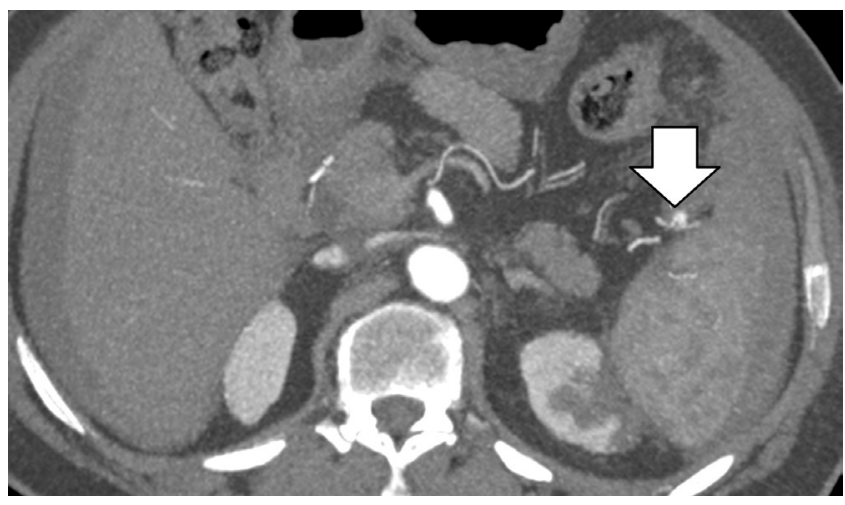

Figure 1. Axial computed tomography image shows perihepatic fluid collection and ruptured splenic artery aneurysm (white arrow)

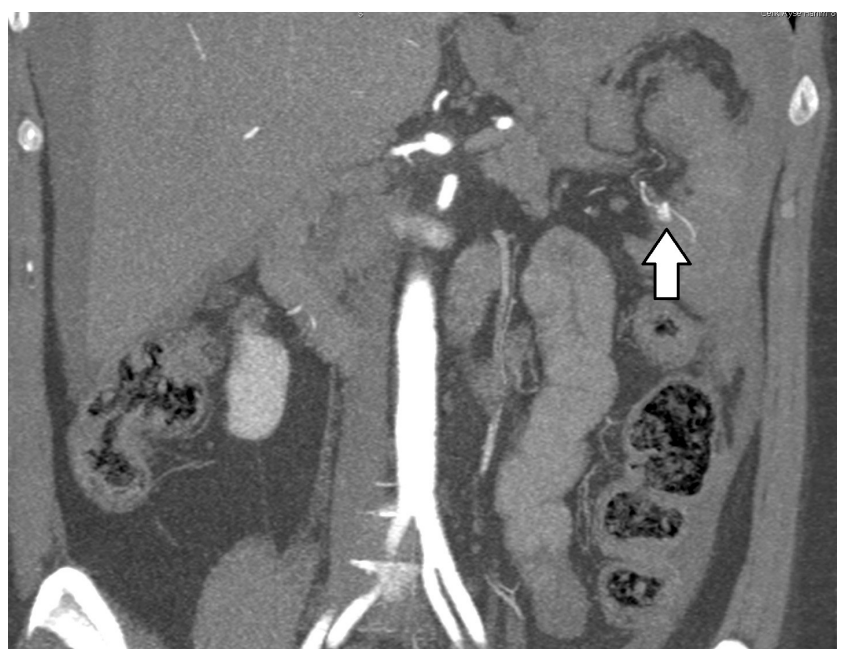

Figure 2. Coronel computed tomography image shows perihepatic fluid collection and ruptured splenic artery aneurysm (white arrow) males (female/male ratio: $4: 1$ ), splenic artery dissection is more common in men $(4,5)$. The most common etiological factor for SAA has been reported to be atherosclerosis, followed by cystic degeneration, trauma, fibromuscular dysplasia, pregnancy, connective tissue diseases and hypertension (6-8). In our case, essential hypertension was the etiologic factor.

When SAA diameter does not exceed $2 \mathrm{~cm}$, clinical signs and symptoms rarely occur. The majority of SAAs are located in the distal and middle parts of the splenic artery (9). In these patients, the presence of abdominal pain in the epigastric region and in the left upper quadrant is not expected. However, some patients suffer from epigastric pain and this pain is often described as chronic and non-specific. In patients with left upper quadrant pain, especially if there is a finding suggestive of hypovolemia, this may be due to aneurysm rupture (10). The reported incidence of SAA rupture varies between $3 \%$ and $10 \%$. Approximately $10 \%$ of SAAs are ruptured at the time of diagnosis with a reported death rate of $36-75 \%(3,11)$. Our patient presented to the ED with similar complaints.

The most common causes of abdominal hemorrhage are of visceral origin, followed by gynecological and vascular causes and coagulopathy. The most common visceral ones are of hepatic, splenic, renal and adrenal origin. The clinical presentation is not specific to the disease, thus, patients are usually diagnosed during surgery (12). When this condition is not taken into consideration, physicians lose a lot of time for diagnosis. This case was an exception and was treated with a prompt diagnosis.

Treatment of SAA should be initiated immediately after diagnosis in patients with high risk of rupture (aneurysm diameter greater than $2 \mathrm{~cm}$ ), symptomatic patients, transplant patients, those with SAA associated with inflammatory processes, and fertile or pregnant women (13). Physicians generally refer patients with an aneurysm greater than $2 \mathrm{~cm}$ to surgery due to the risk of rupture of the aneurysm (6). There are several surgical approaches for SAA: A) resection with or without vascular repair, B) artery ligation with open or laparoscopic surgery, and C) endovascular interventions such as embolization. Classical approach (open or laparoscopy) is a frequently preferred method. Although laparoscopic surgery requires surgical skills, laparoscopy is an excellent and less invasive alternative method. Some difficulties may be encountered in endovascular surgery due to the fact that the anatomical structure of the splenic artery is tortuous (9). Thus, elective surgery can save the spleen in most cases, however, it is almost impossible in emergency cases. Symptomatic splenic cysts larger than $5 \mathrm{~cm}$ should be treated surgically due to increased risk of rupture and, during surgery, attention should be paid to protect the 
splenic parenchyma. Splenectomy is recommended due to the risk of bleeding under the following circumstances:

1) The cyst is large and almost completely covered with splenic parenchyma,

2) The cyst is in the splenic hilum (14).

In conclusion, patients with ruptured SAA may present with non-specific symptoms or symptoms mimicking more common emergent conditions. This clinical presentation may result in hemorrhagic shock or cardiovascular collapse leading to death. Ruptured SAA should be considered in high-risk patients admitted to ED.

\section{Authorship Contributions}

Surgical and Medical Practices: C.B., A.S. Concept: C.B., A.S. Design: C.B., A.S. Data Collection or Processing: C.B., A.S. Analysis or Interpretation: C.B., A.S. Literature Search: C.B. Writing: C.B., A.S.

Conflict of Interest: No conflict of interest was declared by the authors.

Financial Disclosure: The authors declared that this study has received no financial support.

\section{References}

1. Guillon R, Garcier J, Abergel A, et al. Management of splenic artery aneurysms and false aneurysms with endovascular treatment in 12 patients. Cardiovasc Intervent Radiol 2003;26:256-60.

2. Sadat U, Dar O, Walsh S, Varty K. Splenic artery aneurysms in pregnancy-a systematic review. Int J Surg 2008;6:261-5.

3. Chookun J, Bounes V, Ducasse JL, Fourcade O. Rupture of splenic artery aneurysm during early pregnancy: a rare and catastrophic event. Am J Emerg Med 2009;27:898.
4. Takayama T, Miyata T, Shirakawa M, Nagawa H. Isolated spontaneous dissection of the splanchnic arteries. J Vasc Surg 2008;48:329-33.

5. Abbas MA, Stone WM, Fowl RJ, et al. Splenic artery aneurysms: two decades experience at Mayo clinic. Ann Vasc Surg 2002;16:442-9.

6. Mattar SG, Lumsden AB. The management of splenic artery aneurysms: experience with 23 cases. Am J Surg 1995; 169:580-4.

7. Perrot M, Bühler L, Deléaval J, Borisch B, Mentha G, Morel P. Management of true aneurysms of the splenic artery. Am J Surg 1998;175:466-8.

8. Wagner $W H$, Allins $A D$, Treiman $R L$, et al. Ruptured visceral artery aneurysms. Ann Vasc Surg 1997;11:342-7.

9. Diwan A, Sarkar R, Stanley JC, Zelenock GB, Wakefield TW. Incidence of femoral and popliteal artery aneurysms in patients with abdominal aortic aneurysms. J Vasc Surg 2000;31:863-9.

10. Larson PA, Lipchik EO, Adams MB. Development and regression of visceral artery aneurysms following liver transplantation: case report. Cardiovasc Intervent Radiol 1988;11:75-8.

11. Popham $P$, Buettner A. Arterial aneurysms of the lienorenal axis during pregnancy. Int J Obstet Anesth 2003;12:117-9.

12. Willmann JrK, Roos JE, Platz $A$, et al. Multidetector $C T$ : detection of active hemorrhage in patients with blunt abdominal trauma. AJR 2002;179:437-44.

13. Guillaumon AT, Chaim EA. S Splenic artery aneurysm associated with anatomic variations in origin. J Vasc Bras 2009;8:177-81.

14. Labruzzo C, Haritopoulos KN, El Tayar AR, Hakim NS. Posttraumatic cyst of the spleen: a case report and review of the literature. Int Surg 2002;87:152-6. 